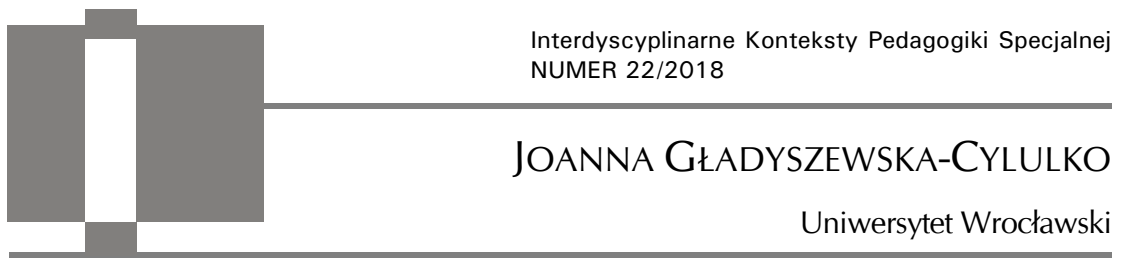

\title{
Autostygmatyzacja osób z niepełnosprawnością wzrokową
}

\begin{abstract}
Joanna Gładyszewska-Cylulko, Autostygmatyzacja osób z niepetnosprawnościq wzrokowa [Self-stigmatisation in the visually impaired]. Interdyscyplinarne Konteksty Pedagogiki Specjalnej, nr 22, Poznań 2018. Pp. 185-200. Adam Mickiewicz University Press. ISSN 2300-391X. DOI: https:/ / doi.org/10.14746/ikps.2018.22.11

The blind and visually impaired are one of the groups prone to being stigmatised. Stigmatization by social environment may lead to self-stigmatisation, that is expressing negative opinions about oneself as a result of the sigma that one carries. Self-stigmatisation usually develops through three stages: first the stigmatised person realizes that they have been stereotyped, then they accept the stereotype and finally apply it to themselves. Thus, for self-stigmatisation to develop in a given person, this person has to be aware that they are perceived by the society in a stereotypical way (a blind person is usually perceived as passive, dependent and reliant on other people's help), accept it and acknowledge themselves that this is what they are like. Not every visually impaired person is bound to develop self-stigmatisation. The article presents selected factors and preventive measures that may reduce the risk of self-stigmatisation.
\end{abstract}

KEY WORDS: self-stigmatisation, the blind, the visually impaired, stigma

Tyflopsycholodzy i tyflopedagodzy są zgodni co do tego, że jednym z najważniejszych zadań edukacji i rehabilitacji osób z niepełnosprawnością wzrokową jest przygotowanie do życia wśród widzących. Można tego dokonać poprzez udzielenie im pomocy w nabyciu sprawności i umiejętności umożliwiających zachowanie 
się zgodnie z rolą, jaką wyznacza wiek i pozycja w środowisku społecznym. Jednakże należy w tym miejscu zauważyć, że adaptacja społeczna nie zależy jedynie od samej osoby z niepełnosprawnością, ale i środowiska, w jakim przebywa, także środowiska ludzi widzących ${ }^{1}$. Niestety, nierzadko bywa tak, że w otoczeniu przeważa tendencja do patrzenia na osoby niewidome i słabowidzące przez pryzmat różnic (przede wszystkim in minus) pomiędzy nimi a widzącymi. W tej sytuacji pożądana byłaby zmiana mentalności społecznej, przede wszystkim dostrzeżenie atutów osób z niepełnosprawnością i udzielenie im pomocy w wykorzystaniu mocnych stron i talentów ${ }^{2}$. Stygmatyzacja społeczna może nie tylko utrudniać proces rehabilitacji osób z niepełnosprawnością wzrokową, ale także powodować powstanie zjawiska autostygmatyzacji ze wszystkimi jej negatywnymi konsekwencjami. I właśnie temu ostatniemu zjawisku pragnę poświęcić moje rozważania. W pierwszej części postaram się wyjaśnić mechanizmy psychologiczne leżące $u$ podstaw stygmatyzacji, a także przedstawić najczęstsze przekonania społeczeństwa na temat funkcjonowania osób z niepełnosprawnością wzrokową. W kolejnej części skupię się na zjawisku autostygmatyzacji, omawiając etapy jej rozwoju, wyszczególniając warunki sprzyjające jej umacnianiu, a także charakteryzując niektóre zachowania osób niewidomych i słabowidzących świadczące o jej zaistnieniu. Moje rozważania zakończą refleksje na temat zapobiegania temu niekorzystnemu zjawisku.

$\mathrm{Na}$ początku moich rozważań nad zjawiskiem autostygmatyzacji osób z niepełnosprawnością wzrokową chciałabym przybliżyć pojęcia stygmatyzacji społecznej i stygmatu (piętna), które leżą u jego podstaw.

Stygmatyzacja społeczna jest odpowiedzią na jednostkowe (lub właściwe szerszej grupie czy kategorii społecznej) piętno. Piętno (stygmat)

1 T. Majewski, Psychologia niewidomych i niedowidzacych, PWN, Warszawa 1983, s. $139-140$.

2 R. Ossowski, Teoretyczne i praktyczne podstawy rehabilitacji, Wydawnictwo Uczelniane WSP, Bydgoszcz 1999, s. 235. 
z kolei jest cechą, która po tym jak zostanie zauważona uświadamia istniejące, choć nie wypowiadane - oczekiwania wobec wyglądu, zachowania, sposobów realizowania ról społecznych ${ }^{3}$.

Piętno jest konstrukcją poznawczą, powstającą w wyniku rodzącego się $\mathrm{w}$ świadomości dysonansu pomiędzy tożsamością oczekiwaną a tożsamością rzeczywistą osoby posiadającej negatywną cechę lub atrybut. Ta rozbieżność dyskredytuje daną osobę 4 .

Choć powodów stygmatyzowania może być wiele (deformacje fizyczne, wady charakteru, rasa, narodowość i wyznanie), to we wszystkich „odmianach piętna (...) można odnaleźć te same właściwości socjologiczne" 5 . Gdy osoba, która mogłaby bez trudu radzić sobie w kontaktach z innymi zostaje naznaczona, spoglądamy na nią z nieufnością lub innymi negatywnymi emocjami nie tylko wtedy, gdy prezentuje ona właściwości, które świadczą o jej słabości, ale i cechy, które w innych okolicznościach mogłyby wywrzeć pozytywne wrażenie. Piętno modyfikuje nasze antycypacje w stosunku do niej, sprawia, że przypisujemy jej cechy, które niekoniecznie musi posiadać, ale które są zgodne z naszym wyobrażeniem $^{6}$. Postrzeganie człowieka w oparciu o tylko jeden, wybijający się na plan pierwszy atrybut powoduje, że patrzymy na niego w sposób uproszczony, jedynie jednowymiarowo, nie zauważając innych jego rzeczywistych cech.

U źródeł stygmatyzacji osób z niepełnosprawnością wzrokową leżą różne mechanizmy psychologiczne ${ }^{7}$, takie jak np. dysonans poznawczy. Może go powodować niezrozumienie niektórych za-

${ }^{3}$ I. Kudlińska, Stygmatyzacja społeczna jako perspektywa teoretyczno-badawcza (na przykładzie badań nad stygmatyzacją ludzi biednych), "Acta Universitatis Lodziensis Folia Sociologica" 2011, nr 38, s. 52.

4 Ibidem, s. 52-53.

${ }^{5}$ E. Goffman, Piętno. Rozważania o zranionej tożsamości, przeł. A. Dzierżyńska, J. Tokarska-Bakir, GWP, Gdańsk 2005, s. 35.

6 Ibidem, s. 34-36.

7 E. Jackowska, Stygmatyzacja i wykluczenie społeczne osób chorujacych na schizofrenię - przegląd badań $i$ mechanizmy psychologiczne, "Psychiatria Polska” 2009, nr 6, s. 664-666. 
chowań osób niewidomych, jak choćby nieodwracanie przez nich głowy w kierunku rozmówcy. Takie zachowanie wywołuje u osoby widzącej nieznającej specyficznych potrzeb osób niewidomych dyskomfort. Może on być zniesiony np. przez próbę wytłumaczenia sobie, że niewidomy się wstydzi, jest nieśmiały, nie ma ochoty na kontakt. Innym mechanizmem psychologicznym może być poczucie przynależności do grup społecznych i identyfikowanie ze „swoimi", czyli tymi, którzy widzą. Grupa osób niewidomych staje się wtedy grupą obcą, którą ocenia się w oparciu o uproszczone schematy i niesprawdzone opinie. Jeszcze inny mechanizm mający zastosowanie $\mathrm{w}$ tym przypadku to zjawisko generalizacji zachowania. Gdy widzimy, że osoba niewidoma nie potrafi przeczytać informacji na tablicy o odjeżdżającym pociągu, możemy stwierdzić, że nie potrafi samodzielnie podróżować. Jeszcze innym mechanizmem jest zjawisko samospełniającej się przepowiedni. Mając stereotypowe wyobrażenie o osobach niewidomych, będziemy zauważali tylko te ich cechy, które będą potwierdzały naszą opinię. Na przykład przekonanie, że niewidomi nie są $\mathrm{w}$ stanie samodzielnie radzić sobie w codziennym życiu, spowoduje zauważanie takich zjawisk, jak to, że $\mathrm{w}$ nowym terenie poruszają się oni z pomocą przewodnika albo że wymagają $\mathrm{w}$ nowej sytuacji opisu pomieszczenia, w którym się znajdują, a niezwracanie uwagi na to, że w licznych sytuacjach znanych nie będą potrzebowali oni tego rodzaju pomocy.

Gdy osoba ma jakiś atrybut świadczący o jej ułomności, jesteśmy skłonni widzieć w niej nie tylko inne wady, ale także inne atrybuty nie całkiem negatywne, lecz nieco kłopotliwe. Wspominając o tym, Erving Goffman przytacza przykład osób niewidomych, które często są traktowane jako posiadające dodatkowo inne ułomności. Ludzie np. mówią do nich głośno, tak jakby byli oni słabo słyszący lub podtrzymują ich, jakby byli chromi. Czasem traktują ich także jako posiadaczy szóstego zmysłu - nadnaturalnego sposobu poznawania rzeczywistości $\mathrm{w}$ sytuacji pozbawienia głównego teleanalizatora ${ }^{8}$.

${ }^{8}$ E. Goffman, op. cit., s. 36. 
Erving Goffman twierdzi, że aby powstała stygmatyzacja, piętno musi być nie tylko widoczne, ale i natarczywe9. Jeśli chodzi o osoby niewidome, to część $\mathrm{z}$ nich ma wyraźnie widoczne cechy $\mathrm{w}$ swym wyglądzie świadczące o ich inności. Na przykład wyraźny oczopląs, wciśnięte w głąb oczodołów gałki oczne, blindyzmy przejawiające się poprzez potrząsanie głową, kołysanie się, zubożenie mimiki. Choć zdarzają się osoby, których piętno jest niewidoczne nawet po dokładniejszym przyjrzeniu się, to jednak i one są identyfikowane jako niewidome na podstawie atrybutów takich jak biała laska, ciemne okulary czy pies przewodnik. Warto w tym miejscu zatrzymać się na chwilę, by utwierdzić się w przekonaniu, że wiedza o osobach z niepełnosprawnością wzrokową, nawet tak pobieżna jak ta dotycząca ich atrybutów, jest aktualizowana na podstawie stereotypowych wyobrażeń nie zawsze mających odzwierciedlenie w rzeczywistości, gdzie np. stosunkowo niewielu niewidomych ma psa przewodnika. Choć piętno osób niewidomych jest zwykle widoczne, nie musi być jednak natarczywe, tzn. nie musi zakłócać interakcji społecznych. Gdy widzimy osobę niewidomą idącą po chodniku i porusza się ona sprawnie, potrafi iść w wytyczonym przez siebie kierunku i nie zakłóca toru przemieszczania się innych osób, to jej piętno jest widoczne, lecz nie przykuwa na tyle uwagi, by je ocenić jako znaczące. Jeśli jednak rozmawiamy z osobą niewidomą i ma ona problem z kierowaniem na rozmówcę wzroku, patrzy w innym kierunku niż on, to wówczas interlokutor może czuć się niekomfortowo $\mathrm{w}$ takiej sytuacji i odbierać jej piętno jako natarczywe.

Na podstawie przeprowadzonych przeze mnie badań dotyczących obrazu osób $\mathrm{z}$ niepełnosprawnością wzrokową $\mathrm{w}$ oczach pełnosprawnego społeczeństwa ${ }^{10}$ mogę stwierdzić m.in., że choć społeczeństwo ma raczej pozytywny obraz osób niewidomych, to jest on stereotypowy. Badani przypisywali osobom z niepełnosprawnością

9 Ibidem, s. 85.

10 J. Gładyszewska-Cylulko, Obraz osoby niepetnosprawnej wzrokowo w oczach petnosprawnego społeczeństwa w kontekście przemian kulturowo-społecznych, „Wychowanie na co dzień" 2013, nr 12, s. 9-13. 
wzrokową takie cechy, jak lękliwość, nadmierną wrażliwość, niską pewność siebie, cierpliwość, powagę. W odpowiedziach badanych ujawniały się także typowe stereotypy dotyczące osób niewidomych, jak choćby przekonanie o ich bierności. Jedną z przyczyn takiego stanu rzeczy mogą być sporadyczne kontakty respondentów z osobami niewidomymi ograniczone zwykle do sytuacji, gdy rzeczywiście potrzebują one pomocy ze strony pełnosprawnego wzrokowo społeczeństwa (np. na przystanku tramwajowym, gdy nie potrafią odczytać numeru podjeżdżającego tramwaju). Może to sprzyjać podziałowi ról na osoby widzące - pomagające (silniejsze, aktywne, zaradne) i osoby niewidome - potrzebujące pomocy (słabsze, bierne, bezradne). Co warte zauważenia podobne wyniki uzyskałam w tak różnych pod względem kulturowo-społecznym krajach jak Polska i Australia11.

Stygmatyzowanie „może przejawiać się w czterech formach - jako nieudzielanie pomocy, unikanie, stosowanie przymusu i segregacja instytucjonalna"12. Osoby stygmatyzujące uważają, że osoby niewidome powinny uczyć się w szkołach specjalnych, pracować w zakładach pracy chronionej. Ponadto są przekonane, że niewidomym jest lepiej we własnym towarzystwie i nie potrzebują kontaktów z widzącymi. Zdaniem Elżbiety Czykwin bycie osobą stygmatyzowaną powoduje zmniejszenie poczucia kontroli, co wpływa na zaufanie do siebie i świata, a także ma wpływ na podejmowanie działań zmierzających do oddziaływania na rzeczywistość, także społeczną ${ }^{13}$. Stygmatyzacja wpływa na obraz samego siebie dlatego, że

postawa stygmatyzującą jest rodzajem negatywnej interakcji społecznej, a zgodnie z fundamentalną wiedzą z zakresu psychologii klinicznej poczucie Ja człowieka w rożnych fazach rozwoju i dorosłości wy-

11 J. Gładyszewska-Cylulko, Postrzeganie możliwości i potrzeb osób niewidomych w Polsce i Australii, „Niepełnosprawność. Dyskursy pedagogiki specjalnej” 2017, nr 26, s. 29-43.

12 P. Corrigan, A. Watson, Understanding the impact of stigma on people with mental illness, „World Psychiatry” 2002, nr 1(1), s. 18.

13 E. Czykwin, Stygmat społeczny, PWN, Warszawa 2007, s. 224. 
kazuje wysoki współczynnik korelacji z jakością relacji interpersonalnych. Zależność ta ma charakter przyczynowo-skutkowy i dwustronny, to znaczy, ze niskie poczucie własnej wartości (krytyczna samoocena) zwiększa prawdopodobieństwo odrzucenia społecznego i izolacji ${ }^{14}$.

Niebezpieczeństwo może pojawić się wtedy, gdy osoby stygmatyzowane kategorię związaną z piętnem uczynią centralną kategorią Ja. Wtedy stanowi ona "spoiwo wiążące różne inne elementy obrazu siebie w spójną całość. Istotą tej spójności jest negatywne emocjonalne naznaczenie oraz internalizacja stereotypowych społecznie danych treści"15. Prowadzi to do poczucia bezbronności, bezwartościowości, zmniejszenia kontroli, a w konsekwencji do destrukcji. E. Czykwin proponuje użycie tu pojęcia „syndromu stygmatu jemioły”, używając analogii do drzewa i rosnącej na nim jemioły. Ta niewielka roślina może doprowadzić do zniszczenia drzewa, pasożytując na nim i zabierając mu wodę i sole mineralne. I tak jak jemioła utrudnia drzewu pobieranie życiodajnego pokar$\mathrm{mu}$, tak i piętno umieszczone w centrum obrazu Ja może powodować działania autoizolacyjne, przez co interakcje (także te wcześniej nawiązane) ulegają spłyceniu lub zerwaniu ${ }^{16}$. W stygmatyzowanej osobie toczy się wciąż konflikt poznawczo-afektywny pomiędzy poznawczą potrzebą spójności a emocjonalną potrzebą autowaloryzacji, gdyż człowiek nieustannie dąży do autoweryfikacji (czyli uspójnienia spostrzeżeń na własny temat) i autowaloryzacji (czyli uspójnienia tych spostrzeżeń $\mathrm{z}$ informacjami pochodzącymi z zewnątrz). Potrzeba autoweryfikacji zdaje się być mimo wszystko silniejsza ${ }^{17}$. Osoby stygmatyzowane podejmują różne sposoby radzenia sobie. Pierwszym z nich może być akceptacja „nowego siebie” dokonująca się na różne sposoby. Innym - opanowanie różnych obszarów aktywności, które na pierwszy rzut oka zdają się być niemożliwe o opanowania. Mogą także używać piętna jako wytłumaczenia róż-

\footnotetext{
14 E. Jackowska, op. cit., s. 657.

15 E. Czykwin, op. cit., s. 212.

16 Ibidem, s. 224.

17 L. A.Pervin, Psychologia osobowości, przeł. M. Orski, GWP, Gdańsk 2005.
} 
nego rodzaju niepowodzeń życiowych. Albo odbierać je jako swego rodzaju błogosławieństwo umożliwiające lepsze zrozumienie świata i ludzi ${ }^{18}$.

Jedną z konsekwencji stygmatyzacji może być autostygmatyzacja. Przebiega ona zwykle w trzech etapach: najpierw u osób naznaczonych piętnem dochodzi do uświadomienia sobie stereotypu, potem następuje zgoda z nim i w końcu zastosowanie go do własnego ja. A więc, by u danej osoby powstała autostygmatyzacja musi być ona świadoma tego, w jaki stereotypowy sposób postrzega ją społeczeństwo (niewidomy w oczach społeczeństwa jest najczęściej bierny, niesamodzielny, uzależniony od pomocy innych) i zgadzać się z tym („Tak, brak wzroku rzeczywiście powoduje, że człowiek ma tendencję do bierności, jest mało samodzielny i potrzebuje pomocy ze strony innych ludzi"). Jednak te dwa etapy nie wystarczą, by zaistniała autostygmatyzacja - potrzebne jest jeszcze uznanie, że samemu się takim jest. Gdy osoba z niepełnosprawnością wzrokową wchodzi w środowisko, oczekuje akceptacji, która według niej jej się należy albo z założenia, albo z powodu posiadania różnego rodzaju atrybutów (np. empatii, kreatywności, chęci współpracy). Tymczasem nie otrzymuje zainteresowania, może spotkać się z obojętnością lub nawet ostracyzmem. W tej sytuacji rodzi się dysonans poznawczy pomiędzy tym, jak widzi siebie $w$ otoczeniu, a jak otoczenie ją spostrzega. Jednym ze sposobów poradzenia sobie $\mathrm{z}$ tego rodzaju dysonansem jest znajdywanie $w$ sobie cech, które uzasadniają negatywne zachowania środowiska $\mathrm{w}$ stosunku do własnej osoby. Na plan pierwszy w spostrzeganiu siebie mogą wybijać się cechy świadczące o małej atrakcyjności społecznej, zaś cechy, które były mocnymi stronami $\mathrm{w}$ konfrontacji $\mathrm{z}$ innymi - mogą stawać się mniej znaczące $w$ ocenie samego siebie. Brak wzroku, lub ograniczenie jego sprawności, może się stać cechą nadrzędną, według której osoba $z$ niepełnosprawnością wzrokową określa swą tożsamość społeczną, ale może być także traktowane nie tylko jako jedna $\mathrm{z}$ cech, ale wstydliwy atrybut, który powinno się ukryć przed świa-

${ }^{18}$ E. Goffman, op. cit., s. 39-44. 
tem. Osoby słabowidzące mogą wtedy ukrywać przed innymi, że źle widzą (udają, że przepisują z tablicy, choć nie są w stanie zobaczyć tego, co na niej zostało napisane, nie korzystają z pomocy optycznych itp.). Mogą także podejmować próby wyeliminowania z obrazu samego siebie "bycie osobą z niepełnosprawnością wzrokową". Na przykład odmawiają nauki brajla, choć zaburzenie widzenia postępuje, niechętnie uczestniczą $\mathrm{w}$ rehabilitacji wzroku, twierdząc, że nie jest im to potrzebne. Zdarza się też, że postępują odwrotnie - podejmują wszystkie możliwe działania mające na celu polepszenie sprawności widzenia albo podejmują próby opanowania umiejętności, które zdają się być im niedostępne z racji zaburzeń widzenia - np. jazdy na nartach, gry w piłkę nożną. Niestety, nawet jeśli uda im się dokonać postępu w tym zakresie, to nie staną się dla widzących pozbawione swej ułomności.

Jak zostało powyżej wspomniane, nie u wszystkich osób z niepełnosprawnością wzrokową rozwinie się zjawisko autostygmatyzacji. Niektórzy badacze uważają, że stygmatyzowanie nie ma wpływu na samoocenę osoby naznaczanej bądź też ten wpływ jest niewielki. Dzieje się tak dlatego, że

nie piętno wpływa na poczucie własnej wartości, ale raczej poczucie własnej wartości kształtuje percepcję i reakcje na doświadczenie stygmatyzacji. Biorąc pod uwagę ten alternatywny pogląd, wszystkie wątpliwości dotyczą istnienia związku między stygmatyzacją a poczuciem własnej wartości, a także wyjaśnienie tego związku ${ }^{19}$.

Warte przytoczenia w tym miejscu są wyniki badań prowadzonych przez Zofię Palak. Dotyczyły one zagadnień skoncentrowanych wokół problematyki obrazu własnej osoby i poziomu samoakceptacji u niewidomej młodzieży. Wynika z nich, że obraz własnej osoby osób niewidomych nie różnił się od obrazu pełnosprawnych wzrokowo rówieśników. Nie było też większych różnic między niewidomymi a widzącymi, jeśli chodzi o poziom samoakceptacji.

19 B. Link i wsp., The Consequences of Stigma for the Self-Esteem of People With Mental Illnesses, "Psychiatric Services” 2001, nr 52(12), s. 1622. 
Należy tu jednak zaznaczyć, że wśród młodzieży niewidomej 91,7\% stanowiły osoby z wrodzonymi zaburzeniami widzenia lub też te, u których nieprawidłowości zaistniały przed piątym rokiem życia, a więc można przypuszczać, że czynnikami znacznie ułatwiającymi samoakceptację $w$ tej grupie były: wczesne podjęcie działań rehabilitacyjnych, uznanie poziomu stanu fizycznego za wartość stałą ${ }^{20}$. Akceptacja własnej niepełnosprawności była także najważniejszym determinantem minimalizacji poczucia inności osób niewidomych i osób z resztkami wzroku w badaniach prowadzonych przez Marzennę Zaorską. Czynnik ten był nawet ważniejszy niż akceptacja ze strony najbliższego otoczenia społecznego. $\mathrm{W}$ badaniach tych odkryto także, że silniejsze poczucie inności mają osoby, których edukacja przebiega lub przebiegała w systemie szkolnictwa ogólnodostępnego lub integracyjnego ${ }^{21}$. W tym miejscu pragnę wspomnieć także o badaniach przeprowadzonych przez Bruce'a Linka i współpracowników. Dotyczyły one wpływu stygmatyzowania na samoocenę osób chorych psychicznie. Ich wyniki przyczyniły się do zrozumienia roli, jaką piętno odgrywa w życiu ludzi chorych psychicznie $\mathrm{w}$ wielu aspektach. Wbrew twierdzeniu, że stygmatyzacja jest względnie nieistotna, uzyskane wyniki sugerują, że napiętnowanie ma znaczący wpływ na samoocenę osób chorych psychicznie. Badacze oparli się na teorii socjopsychologicznej, w jej ramach tłumacząc mechanizm, za pomocą którego stygmat dotyka ludzi. Jednak ponieważ stygmatyzacja może wpływać na ludzi na wiele sposobów, postulują oni, aby w prowadzonych przyszłych badaniach zmierzać do dokładnego określenia, czym są te mechanizmy, aby można było opracować efektywne interwencje ${ }^{22}$.

Jak widać, ludzie różnie radzą sobie w sytuacji stygmatyzacji. Niektórzy stygmatyzowani odczuwają słuszny w tej sytuacji gniew

20 Z. Palak, Obraz własnej osoby młodzieży niewidomej, UMCS, Lublin 1988, s. 58-155.

${ }^{21}$ M. Zaorska, Poczucie "Inności" u osób niewidomych $i$ osób z resztkami wzroku w sferze funkcjonowania psychicznego, fizycznego i emocjonalnego, "Interdyscyplinarne konteksty pedagogiki specjalnej" 2013, nr 1, s. 37-59.

22 B. Link i wsp., The Consequences of Stigma for the Self-Esteem of People With Mental Illnesses, „Psychiatric Services” 2001, nr 52(12), s. 1621-1626. 
dotyczący tego, jak są traktowani i rozpoczynają walkę z krzywdzącymi je stereotypami, jeszcze nie przejmują się opiniami z zewnątrz. Obecnie badacze podejmują próby znalezienia przyczyny zróżnicowania pomiędzy osobami stygmatyzowanymi. Próbowano wyjaśnić istniejące różnice poprzez podkreślanie, że samoocena kształtuje się $\mathrm{z}$ reguły we wczesnym dzieciństwie, zatem $\mathrm{u}$ dzieci z pozytywną samooceną spotkanie się $\mathrm{z}$ naznaczaniem, $\mathrm{np}$. w momencie rozpoczęcia edukacji szkolnej, nie ma dużego znaczenia (podczas gdy $\mathrm{u}$ tych, których samoocena bazująca na doświadczeniach z wczesnego dzieciństwa była niska, doświadczenia związane z stygmatyzującą postawą otoczenia mogą powodować autostygmatyzację). Są koncepcje zakładające także, że autostygmatyzacja nie powstaje, gdyż stosunek otoczenia jest raczej ambiwalentny niż jednolicie negatywny. Uczucia odrazy, wrogości i unikania współistnieją z poczuciem współczucia, często są też tłumione i nieokazywane. Niestety, jest to sprzeczne $\mathrm{z}$ dowodami, że społeczeństwo prezentuje zachowania świadczące o nieakceptacji, nawet jeśli nie towarzyszy im określona postawa. Ma to miejsce w szczególności, gdy wyrażanie uprzedzeń nie jest społecznie niepożądane lub gdy ludzie nie potrafią kontrolować swego zachowania ${ }^{23}$. Jennifer Crocker i Brenda Major sugerują, że osoby stygmatyzowane mogą stosować mechanizm zachowania polegający nie tyle na porównywaniu się do osób stygmatyzujących, co do innych stygmatyzowanych podobnych sobie. Pozwala to im skupić się na cechach i jakościach innych niż te, które są stygmatyzowane ${ }^{24}$. Doświadczenia kliniczne pokazują, że w przypadku dzieci i młodzieży niewidomych przebywanie $\mathrm{w}$ otoczeniu młodych ludzi podobnych im (np. w ośrodkach szkolno-wychowawczych) może być czynnikiem chroniącym przed autostygmatyzacją. Skłonność do autostygmatyzacji będzie zależała także od tego, jak szybko w swoim życiu osoba zetknie się z przejawami stygmatyzacji (inaczej może być w przypadku osób niewidomych od urodzenia, inaczej ociemniałych w dojrzałym wieku).

${ }^{23}$ J. Crocker, B. Major, Social Stigma and Self-Esteem: The Self-Protective Properties of Stigma, „Psychological Review” 1989, nr 96(4), s. 611-612.

24 Ibidem, s. 614-615. 
Ale jednocześnie badacze podkreślają, że ważniejszy od wieku, gdy zaczął się proces stygmatyzacji, jest czas, jaki upłynął od momentu nabycia piętna. Im ten czas jest dłuższy tym istnieje większe prawdopodobieństwo, że osoba nabyła już pewnych strategii radzenia sobie z piętnem ${ }^{25}$.

Autostygmatyzacja jest zjawiskiem bardziej złożonym niż początkowo zakładano. Wraz z pogłębianiem spojrzenia na zagadnienia $\mathrm{z}$ nią związane powstają nowe wątpliwości, nowe wątki poboczne wymagające wyjaśnienia, nowe teorie potrzebujące dopracowania. Badacze nie mają raczej wątpliwości, że jest to istotne zagadnienie dla kwestii związanych z jakością życia, emancypacją czy autonomią osób z niepełnosprawnością. W wyniku internalizacji stygmy zaczynają one akceptować dyskryminujące postawy społeczne, „co jeszcze bardziej obniża ich poczucie własnej wartości, doprowadzając do unikania jakichkolwiek wyzwań społecznych (np. starania się o pracę)"26. Postulują, by do tej pory opracowane teorie były testowane na różnych subpopulacjach, podobnie jak modele zapobiegania temu zjawisku i likwidowania go. Naukowcy powinni zbadać np. czy zmiany wynikające z interwencji antystygmatyzacyjnych są utrzymane $\mathrm{w}$ czasie ${ }^{27}$.

$\mathrm{Z}$ powodu luk $\mathrm{w}$ wiedzy na temat autostygmatyzacji trudno przedstawić jakieś uniwersalne rady dotyczące zapobiegania negatywnym jej skutkom. Można jednakże próbować zastosować pewne sposoby zapobiegania, z zastrzeżeniem, by każdorazowo dobierać je stosownie do jednostkowych przypadków. Według E. Czykwin takimi sposobami mogą być np. nieukrywanie stygmatu, gdyż może to wyzwalać lęk przed zdemaskowaniem, co może z kolei powodować izolację od innych ludzi lub też tworzenie zdystansowanych lub pozornie bliskich związków. Zamiast tego proponuje ona ujawnienie stygmatu $\mathrm{w}$ kontaktach $\mathrm{z}$ innymi osobami, co da jego nosicie-

25 Ibidem, s. 619.

${ }^{26}$ M. Podogrodzka-Niell, M. Tyszkowska, Stygmatyzacja na drodze zdrowienia w chorobach psychicznych - czynniki zwiazane z funkcjonowaniem społecznym, "Psychiatria Polska" 2014, nr 48(6), s. 1204.

27 P. Corrigan, A. Watson, op. cit., s. 16-20. 
lowi możliwość wyboru sposobu przekazania informacji o stygmacie i ich zakresu. Innym polecanym sposobem może być edukowanie lęku pomiędzy przedstawicielami mniejszości i większości wynikającego z braku wiedzy lub braku kontaktów między nimi poprzez zastosowanie humoru, prezentowanie postaw akceptacji i szacunku'28.

Badacze zajmujący się problematyką autostygmatyzacji chorych psychicznie uważają także, że stosunek do siebie jako osoby niepełnosprawnej można przedstawić na kontinuum, którego jeden kraniec stanowi samonaznaczanie, drugi zaś - poczucie podmiotowości. Na pierwszym krańcu kontinuum są zatem osoby, które nie są w stanie przezwyciężyć negatywnych oczekiwań i stereotypów na temat choroby psychicznej. Mają niską samoocenę i niewielkie zaufanie do ich przyszłego sukcesu. Na drugim zaś ci, którzy, pomimo tej niepełnosprawności, mają pozytywną samoocenę i nie są znacząco obciążone publicznym piętnem. Zamiast tego wydają się być pobudzeni przez napiętnowanie do upodmiotowienia. Czynnikiem istotnym $w$ tym zakresie zdaje się być identyfikacja z grupą stygmatyzowaną. Choć z jednej strony osoby stygmatyzowane, wchodząc $\mathrm{w}$ bliskie relacje $\mathrm{z}$ podobnymi im osobami, mogą internalizować negatywne oczekiwania kierowane do siebie, to $\mathrm{z}$ drugiej strony pozytywne doświadczenia $\mathrm{w}$ grupie osób im podobnych mogą wpływać pozytywnie na ich stosunek do siebie samych i poczcie własnej skuteczności. Zatem identyfikacja z grupą osób z takim samym rodzajem niepełnosprawności może jest czynnikiem ochronnym, który zmniejsza prawdopodobieństwo, że dana osoba zgodzi się z publicznym piętnem i zastosuje je do siebie. Zapobieganie autostygmatyzacji będzie polegało na podejmowaniu takich działań, które spowodują niepojawienie się przynajmniej jednego z trzech warunków zaistnienia autostygmatyzacji, które przedstawiłam w początkowej części mego artykułu. Prócz istnienia pozytywnych kontaktów z przedstawicielami swojej grupy ważna zdaje się być także praca poznawcza nad przekonaniami (nie tyle na temat siebie

${ }^{28}$ E. Czykwin, op. cit., s. 268-275. 
samego, co nad istotą przekonań), wiedza na temat mechanizmu stygmatyzacji itp. ${ }^{29}$.

Patrick Corrigan i Amy Watson uważają, że walka z krzywdzącym stereotypowym podejściem do osób stygmatyzowanych może polegać na stosowaniu trzech strategii. Pierwszą z nich jest protest wysyłany przez środowiska osób stygmatyzowanych wszędzie tam, gdzie przedstawiany jest nieprawdziwy obraz osób naznaczanych. Ponadto edukacja polegająca na przeprowadzaniu kampanii ukazujących prawdziwy obraz osób stereotypowo dotąd odbieranych, a po trzecie kontakt $\mathrm{z}$ tymi osobami ${ }^{30}$. W przypadku osób z niepełnosprawnością wzrokową przykładami takich strategii mogą być kampanie społeczne takie jak „Czy naprawdę jesteśmy inni?” prezentowane przez Stowarzyszenie Przyjaciół Integracji, albo „Support Scent" organizowana przez organizację Guide Dogs Australia czy „Niewidziana Wystawa” - miejsce, gdzie osoby widzące mogą spojrzeć na świat z punktu widzenia osoby niewidomej.

Na początku mojego artykułu przytoczyłam słowa Tadeusza Majewskiego, że jednym z głównych zadań edukacji i rehabilitacji osób niewidomych i słabowidzących jest przygotowanie ich do życia wśród widzących poprzez pomoc w nabyciu tych umiejętności i sprawności, które zgodne są z rolą wyznaczoną przez wiek i pozycję w środowisku społecznym. Myślę, że w tym aspekcie największym niebezpieczeństwem autostygmatyzacji osób z niepełnosprawnością wzrokową jest to, że przyjmując stygmat, zaczynają się zachowywać zgodnie z błędnymi oczekiwaniami społeczeństwa. Nadana etykieta zrasta się z nimi, jest asymilowana, traktowana jako prawdziwa, oczywista, bezdyskusyjna. Autostygmatyzacja może stać się główną przeszkodą w odgrywaniu ról społecznych i funkcjonowania tak w środowisku osób widzących, jak i poza nim. Może wpływać negatywnie na stosunek do samego siebie, utrudniać podejmowanie działań zmierzających do polepszenia swej sytuacji,

${ }^{29}$ A. Watson i wsp., Self-Stigma in People With Mental Illness, "Schizophr Bull." 2007, nr 33(6), s. 1312-1318.

30 P. Corrigan, A. Watson, op. cit., s. 16-20. 
blokuje chęć zdobywania nowych celów oraz realizowania planów i marzeń. Mówiąc jeszcze szerzej - może utrudniać podejmowane działania związane z edukacją i rehabilitacją, a także wpływać negatywnie na procesy autonomii czy emancypacji. Dlatego myślę, że zjawisko stygmatyzacji warte jest przybliżenia i dokładniejszego poznania, szczególnie $\mathrm{w}$ aspekcie odnalezienia czynników mu zapobiegających. Choć niewątpliwie trudno jest wyeliminować z przestrzeni społecznej istniejące stereotypy, trudno jest zmienić obraz samego siebie jako osoby, która uległa autostygmatyzacji, to jednak można zintensyfikować działania ukierunkowane na wzmacnianie pozytywnego obrazu samego siebie u osób niewidomych i słabowidzących, polepszenie ich kontaktów społecznych (zarówno ze środowiskiem osób pełnosprawnych, jak i niepełnosprawnych wzrokowo), zwiększanie ich poczucia podmiotowości, a także rozwijanie ich autonomii i podwyższanie jakości życia w różnych sferach.

\section{Bibliografia}

Crocker J., Major B., Social Stigma and Self-Esteem: The Self-Protective Properties of Stigma, „Psychological Review” 1989, nr 96(4).

Corrigan P., Watson A., Understanding the impact of stigma on people with mental illness, „World Psychiatry” 2002, nr 1(1).

Czykwin E., Stygmat społeczny, PWN, Warszawa, 2007.

Gładyszewska-Cylulko J., Obraz osoby niepetnosprawnej wzrokowo w oczach petnosprawnego społeczeństwa w kontekście przemian kulturowo-społecznych, „Wychowanie na co Dzień" 2013, nr 12.

Gładyszewska-Cylulko J., Postrzeganie możliwości i potrzeb osób niewidomych w Polsce i Australii, „Niepełnosprawność. Dyskursy pedagogiki specjalnej” 2017, nr 26.

Goffman E., Piętno. Rozważania o zranionej tożsamości, przeł. A. Dzierżyńska, J. Tokarska-Bakir, GWP, Gdańsk, 2005.

Jackowska E., Stygmatyzacja i wykluczenie społeczne osób chorujacych na schizofrenię przeglad badań i mechanizmy psychologiczne, „Psychiatria Polska” 2009, nr 6.

Kudlińska I., Stygmatyzacja społeczna jako perspektywa teoretyczno-badawcza (na przykładzie badań nad stygmatyzacja ludzi biednych), „Acta Universitatis Lodziensis Folia Sociologica" 2011, nr 38.

Link B. i wsp., The Consequences of Stigma for the Self-Esteem of People With Mental Illnesses, „Psychiatric Services” 2001, nr 52(12). 
Majewski T., Psychologia niewidomych i niedowidzacych, PWN, Warszawa 1983.

Ossowski R., Teoretyczne i praktyczne podstawy rehabilitacji, Wydawnictwo Uczelniane WSP, Bydgoszcz 1999.

Palak Z., Obraz własnej osoby młodzieży niewidomej, UMCS, Lublin 1988.

Pervin L.A., Psychologia osobowości, przeł. M. Orski, GWP, Gdańsk 2005.

Podogrodzka-Niell M., Tyszkowska M., Stygmatyzacja na drodze zdrowienia w chorobach psychicznych - czynniki zwiazane z funkcjonowaniem spotecznym, „Psychiatr. Pol." 2014, nr 48(6).

Watson A. i wsp., Self-Stigma in People With Mental Illness, "Schizophr Bull." 2007, nr 33(6).

Zaorska M., Poczucie "Inności” u osób niewidomych i osób z resztkami wzroku w sferze funkcjonowania psychicznego, fizycznego i emocjonalnego, „Interdyscyplinarne konteksty pedagogiki specjalnej" 2013, nr 1. 